http://kitaibelia.unideb.hu/

ISSN 2064-4507 (Online) • ISSN 1219-9672 (Print)

(C) 2016, Department of Botany, University of Debrecen, Hungary

21 (2): 207-212.; 2016

DOI: $10.17542 /$ kit.21.207

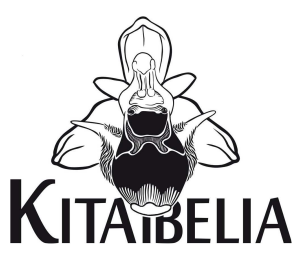

\title{
Az egyvirágú here (Trifolium ornithopodioides (L.) Sm.) „újrafelfedezése” a Hortobágyon
}

\author{
NóTÁRI Krisztina ${ }^{1}$, JAKAB Gusztáv² \& PIFKó Dániel ${ }^{3}$
}

(1) Debreceni Egyetem, Természettudományi és Technológiai Kar, Növénytani Tanszék, H-4010 Debrecen, Egyetem tér 1.; notari.krisztina@gmail.com

(2) Szent István Egyetem, Gazdasági, Agrár- és Egészségtudományi Kar, Víz- és Környezetgazdálkodási Intézet, H-5540 Szarvas, Szabadság út 1-3.

(3) Magyar Természettudományi Múzeum, Növénytár, H-1088 Budapest, VIII. Könyves K. krt. 40.

\section{The 'rediscovery' of the Birdsfoot Fenugreek (Trifolium ornithopodioides (L.) SM.) in the Hortobágy, Hungary}

\begin{abstract}
In 2009, the first author discovered an unknown population of Trifolium ornithopodioides in the Ágota-puszta of Hortobágy plain. In 2016, the second author found an another population in the vicinity of Karcag (Ecse-zug puszta). Up to now there was only one published occurrence of this species from the region. The specimen collected by Szujkó-Lacza Júlia, Kováts Dezső and Fekete Gábor in 1974 was deposited in the herbarium of the Hungarian Natural History Museum (BP), but this incomplete specimen was misidentified, and not Trifolium ornithopodioides. Therefore, this newly discovered site at Ágota-puszta should be regarded as the first trustworthy occurrence of this species at the Hortobágy plain.
\end{abstract}

Keywords: alkaline grasslands, Crisicum, Fabaceae, floristics, herbarium

Összefoglaló - Az első szerző 2009 nyarán a Hortobágyon található Ágota-puszta délkeleti részén megtalálta az egyvirágú here (Trifolium ornithopodioides) vegetatív állapotú egyedeit. A növény a megtalálás helyén egy ősmedervonulat szikfok-zónájában él. A faj másik állományát 2016-ban a második szerző találta a karcagi Ecse-zugban, kiszáradt, legelt ecsetpázsitosban. Az egyvirágú herének a Hortobágyról csak egy adata volt ismert ezidáig, melyet SzujKó-LACZA et al. (1982) publikált egy 1974-es gyűjtés alapján. A gyűjtés bizonyító példánya, amely a Magyar Természettudományi Múzeum Növénytárában (BP) található, rosszul határozható, hiányos példány, de a pálhalevelek vizsgálata alapján feltételezhető, hogy nem Trifolium ornithopodioides egyede van a lapon. Így tehát a 2009-es észlelés az egyvirágú here első hiteles adata a Hortobágyról.

Kulcsszavak: Fabaceae, florisztika, herbárium, szikesek, Tiszántúl

\section{Bevezetés}

Az egyvirágú here a Trifolium L. nemzetség Falcatula (Brot.) Coombe alnemzetségébe tartozik. Kis teremtü, 5-10, ritkán $30 \mathrm{~cm}$ magasra megnövő, többnyire kopasz, villásan elágazó, elfekvő szárú, egyéves életformájú, május-júniusban virágzó növény. A hármasan összetett levelek levélkéi ék-visszástojásdad alakúak, erősen fogazott szélűek, kicsípett csúcsúak, ék vállúak, mindegyik levélke nyele rövid. A pálhák 7-10 mm hosszúak, lándzsásak, kihegyezett csúcsúak. A 6-8 mm hosszú, fehér vagy halvány rózsaszín virágok a levelek hónaljában nálunk egyesével vagy ritkán két-háromtagú, másutt magányosan vagy 2-4 tagú ernyőben 
állnak. A csésze tíz erű, fogai egyformák, háromszögű alapból szálasak és kopaszak. A hosszúkás, enyhén görbült hüvely 5-10 magvú (COOMBE 1968, LESKU \& MOLNÁR 2007, ANON. 2009, KóRA 2011, JAKAB 2012), a növény obligát autogám (HERRMANN \& LINKE 2006), az ezermagtömege 0,8133 g (TöRöK et al. 2013). Az egyvirágú here atlanti-mediterrán elterjedésű, szórványos előfordulású sótűrő faj, ami a nyugat- és dél-európai tengerpartokon elterjedt és a kontinens belsejéből csak a Kárpát-medence szikeseiről ismert (LESKU \& MoLNÁR 2007). Elterjedésének súlypontja Nyugat-Európában és Közép-Európa nyugati részén van (BoRHIDI 1995), adatai Nagy-Britannia, Írország, Hollandia, Németország, Franciaország, Portugália, Spanyolország, a Baleár-szigetek, Korzika, Szardínia, Olaszország, Magyarország és Románia területéről vannak (COOMBE 1968, DiHORU \& NEGREAN 2009). COOMBE (1968) szerint az azoriszigeteki és a volt jugoszláviai előfordulása bizonytalan, ám a Debreceni Egyetem és a Növénytár gyűjteményében találhatók szerbiai példányok. Európán kívül ÉszaknyugatAfrikában fordul elő (WEBB et al. 1988), illetve behurcolva Kanada keleti partján időleges megtelepedését tapasztalták (BRoulLLET et al. é.n.), Dél-Afrikába és Ausztráliába is behurcolták (HERRMANN \& LinKE 2006), Új-Zélandon (ALLAN 1936) pedig száraz, gyomos helyeken, folyópartokon közönségessé vált (WEBB et al. 1988).

Hazánkban a Körösöktől délre elterjedt, ezen belül is a Kis-Sárréten és a Csanádipusztákon a leggyakoribb, a Békés-Csanádi-löszhátról, a Dévaványai-síkról és a NagySárrétről viszont hiányzik (JAKAB 2005, 2012) (1. ábra). Régi adatai vannak a szomszédos Bánságból, Partiumból (DiHORU \& NEGREAN 2009), valamint a Kiskunságból is (SzUJKó-LACZA \& KovÁTS 1993).

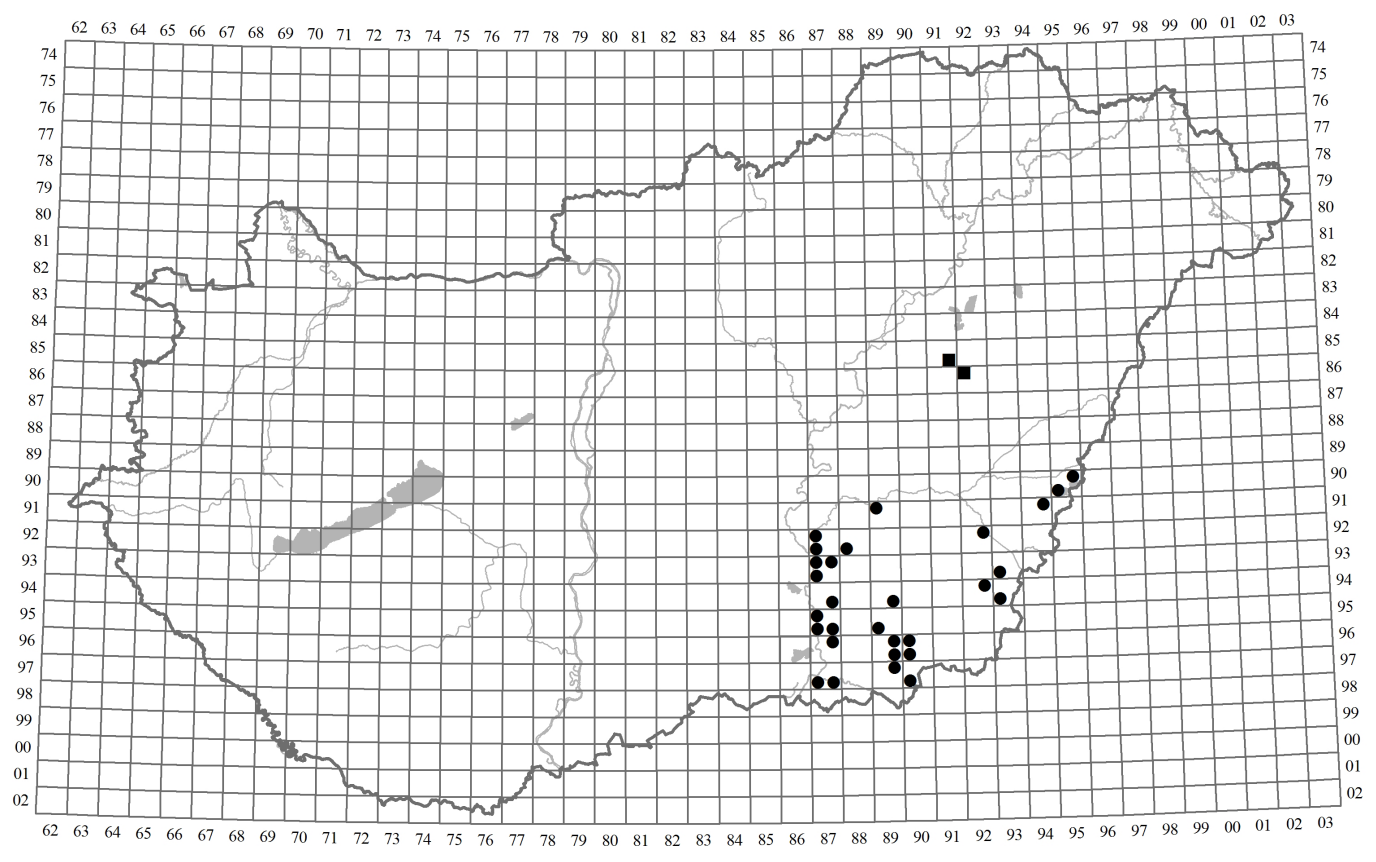

1. ábra. Az egyvirágú here (Trifolium ornithopodioides) hazai előfordulása a Magyar Flóratérképezési Program adatbázisa (NymE EMK NTI) alapján (körök) (JAKAB et al. 2015), kiegészítve az új adatokkal (négyzetek)

Fig. 1. Distribution of Trifolium ornithopodioides in Hungary according to the database of the Hungarian Flora mapping Program (circles) (JАKAB et al. 2015) supplemented by the new records (squares)

BORHIDI (1995) szerint hazánkban az egyvirágú here bázikus, magas sótartalmú, szélsőségesen tápanyagszegény talajokon, szélsőségesen változó vízhatású termőhelyeken él, sziki 
rétek és ürmös szikes puszták tavasszal víz alatt álló részein, a kiszáradó iszapfelszíneken rövid idő alatt éli le a teljes életciklusát (JAKAB 2012). Ennek ellenére az európai szakirodalomban sókerülő, enyhén mészkerülő növényként is szerepel, ami tápanyagban szegény savanyú homokon, kavicson, sós mocsarakban, partfalakon él a tengerparti sávban (CoOMBE é.n.), Németországban a legeltetett tengerparti Lolio perennis - Cynosuretum cristati (Br.-Bl. et De Leeuw 1937) Tüxen 1937 társulás tagja (HERRMAnN \& LinkE 2006).

Hazánkban aktuálisan veszélyeztetett (KIRÁLY 2007), Romániában súlyosan veszélyeztetett (DIHORU \& NEGREAN 2009), a rétek kiszárítása és a legeltetés megszűnése által az élőhelyének megszűnése fenyegeti. SIMON (1997) kategóriarendszerében természetes pionírként, BORHIDI (1995) rendszerében ritka generalistaként szerepel, mivel széles ökológiai tűrőképességü faj, ami sokféle termőhelyen és társulásban megtalálja életfeltételeit, ám az antropogén behatást jellemzően rosszul, az erős legeltetést viszont jól tűri (JAKAB 2012). Védett növény, természetvédelmi értéke 5000 Ft (13/2001. (V.9.) KöM rendelet).

\section{Eredmények}

2009. július 10-én Nótári Krisztina, a Hortobágyi Kutatótábor résztvevőjeként Püspökladány határában, Ágota-puszta délkeleti részén fekvő Nagy-Dögös határrészen (KEF: 8692.1; N $47.360475^{\circ}$ E $21.079336^{\circ}$ ), egy ősmedervonulat szikfok-zónájában megtalálta az egyvirágú here vegetatív példányait (2. ábra A). A növényeket talajmintavétel alkalmával figyelte meg, az előfordulást fotóval dokumentálta. A határozásra alkalmas begyűjtött hajtásból herbáriumi példány készült. A növény élőhelye közelében található egy hodály, a területet birkával és marhával legeltetik. A száraz, meleg nyár folyamán kiszáradt talajt az egyvirágú here környezetében alacsony borítású, jórészt elszáradt szikfoknövényzet borította.

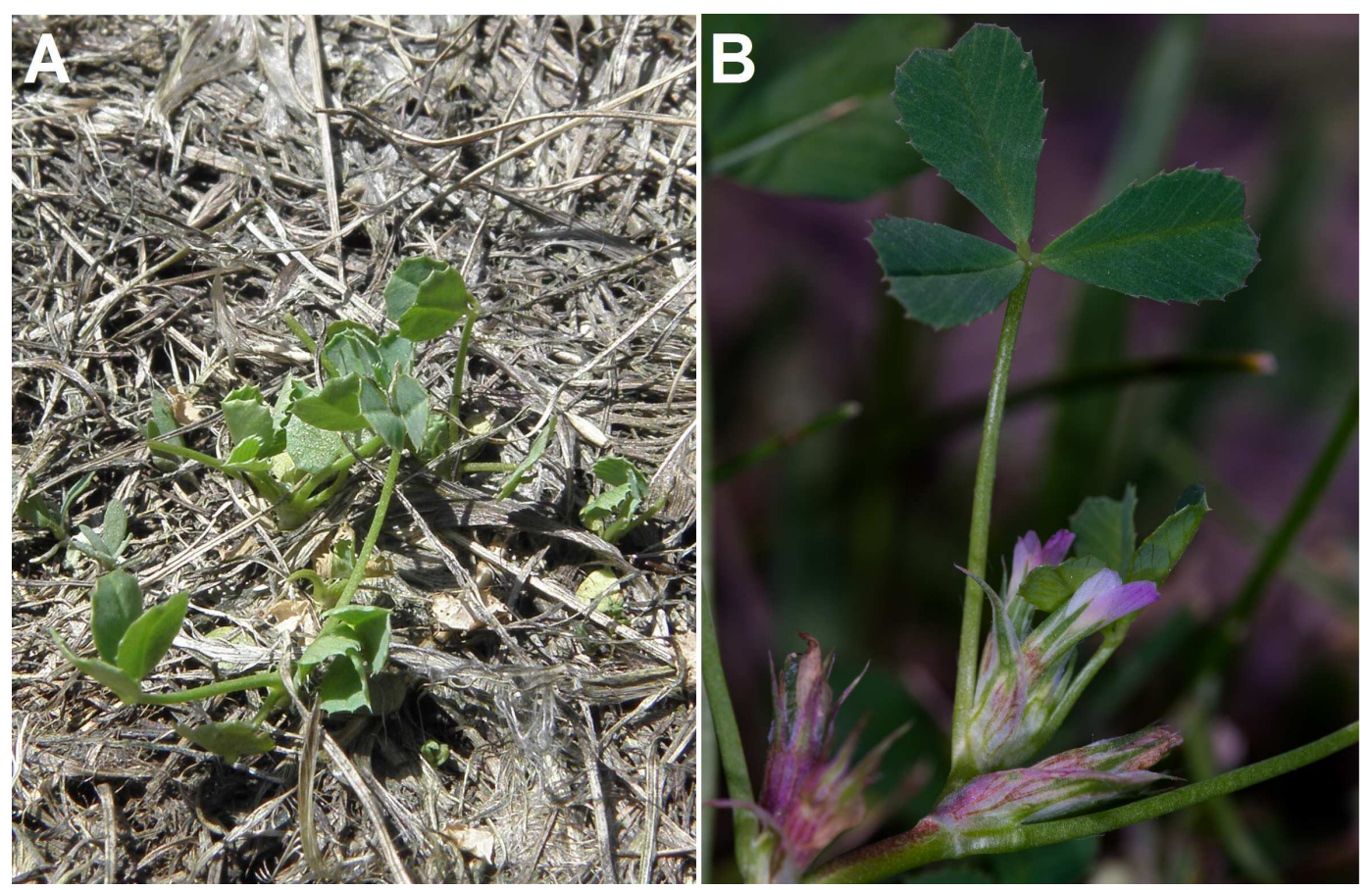

2. ábra. T. ornithopodioides az Ágota-pusztán, 2009 (A) (fotó: Ulicsni Viktor) és Ecse-zugban, 2016 (B) (fotó: Jakab Gusztáv)

Fig. 2. T. ornithopodioides in Hortobágy, Ágota-puszta, 2009 (A) (photo by V. Ulicsni) and in Ecse-zug, 2016 (B) (photo by G. Jakab) 
2016. május 20-án ettől 10 km-re Jakab Gusztáv is megtalálta Karcag külterületén, Ecsezugban (KEF: 8591.4; N 47.416727 ${ }^{\circ}$ E $20.962694^{\circ}$ ). Az 1-2 hektáron talált ezres nagyságrendű állomány egykori rizsföld helyén kialakult legelt, taposott, kiszáradó ecsetpázsitosban, a Békés megyei élőhelyekhez hasonló helyen él (2. ábra B).

A Hortobágyi Nemzeti Park megalakulása után készült flóramúben szerepel a faj adata a Nagyiváni-pusztáról, Szujkó-Lacza Júlia, Kováts Dezső és Fekete Gábor 1974-es gyűjtésére hivatkozva (SzUjKó-LACZA et al. 1982). Ezután nem jelezték a Hortobágyról a kései tavaszi fagyok miatt ott valószínűleg egyébként is ritka növényt, és a Hortobágyról feltételezhetően kipusztultként tartották számon (LESKU \& MoLNÁR 2007). A Magyar Természettudományi Múzeum Növénytárban elhelyezett (BP 469527 „Hung. orientalis Hortobágy, Nagyiván, Nagy-

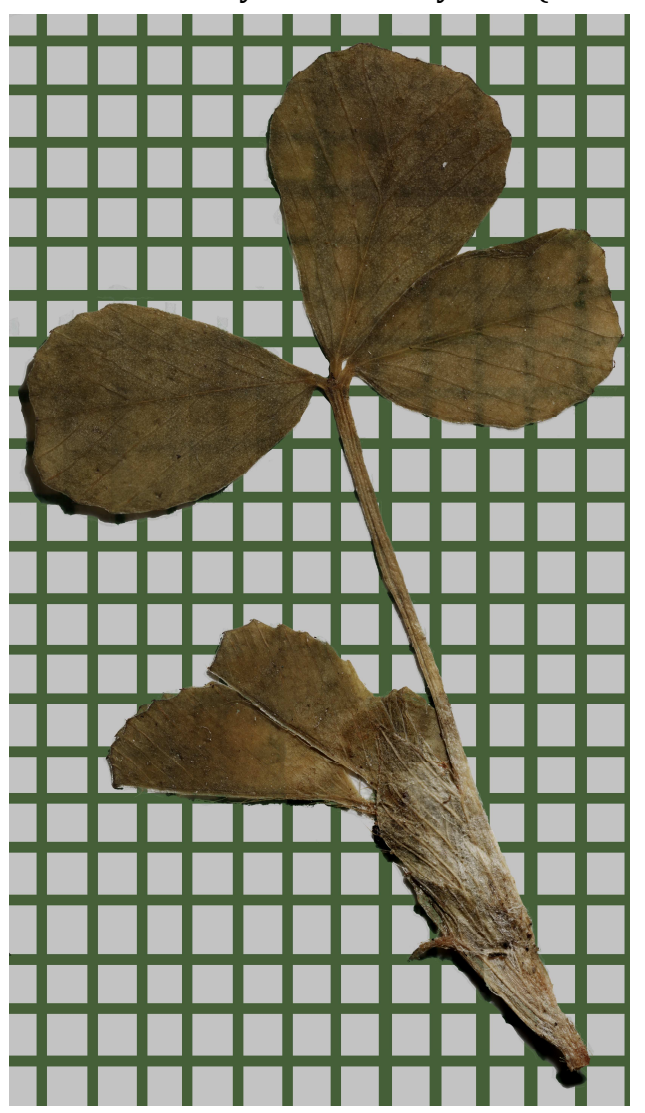
iváni puszta." 23. 05. 1974., Szujkó-Lacza J., Kováts D. és Fekete G.) (3. ábra) példányon egyetlen, alig $2 \mathrm{~cm}$-es növény található, amelyen semmilyen generatív bélyeg nincsen. A határozáshoz egyedül a pálhalevelet tudtuk tanulmányozni.

$\mathrm{Az}$ egyvirágú here pálhalevelei többékevésbé hártyásak, a középső ere jelentősen hosszabb, mint a pálhalevél lemeze, ezért a pálhalevél csúcsa hosszan kihegyezett. A gyűjtött példányon egy pálhalevél pár van, amely szélesebb, nem hártyás és a csúcsa nem kihegyezett. Valószínúleg egy Medicago-faj egyede található a lapon, de a példány nem alkalmas biztos határozásra. Mindenesetre nem tekinthető az egyvirágú here hortobágyi bizonyító példányának, így az egyvirágú here hortobágyi előfordulásáról az első hiteles adat a faj 2009-es megtalálásához köthető.

3. ábra. A tévesen T. ornithopodioides-ként határozott hortobágyi példány (BP 469527; Szujkó-Lacza Júlia, Kováts Dezső és Fekete Gábor gyűjtése; Nagyivánipuszta, 1974) (fotó: Barti Benjámin)

Fig. 3. The specimen (BP 469527) collected by SzujkóLacza J., Kováts D. and Fekete G. in Nagyiváni-puszta (Hortobágy) misidentified as T. ornithopodioides (photo by B. Barti)

\section{Megvitatás}

Az egyvirágú here új védett faj a Horotbgyi Nemzeti Park flórájára. Mind hazánkban, mind külföldön (HERRMANN \& LINKE 2006) elterjedtebb fajnak tűnik, mint korábban gondolták, csak kis mérete, speciális élőhelye és rövid élete miatt ritkán kerül szem elé, így a természetvédemi státuszbesorolása változhat.

\section{Helyreigazítás}

Magyarország edényes növényfajainak elterjedési atlaszában (BARTHA et al. 2015) az egyvirágú here elterjedési térképén az ágota-pusztai adat tévedésből a 8692.2 nagyedkvadrátban szerepel, e cikk 1. ábráján ez már helyesen a 8692.1 negyedkvadrátban van jelölve. 


\section{Köszönetnyilvánítás}

Köszönjük Csathó András István lektori munkáját, Molnár Attila, Molnár V. Attila és Takács Attila észrevételeit, Ulicsni Viktor és Barti Benjámin fényképeit, valamint Schmidt Dávidnak és Tiborcz Viktornak az aktualizált hazai előfordulási térkép elkészítését. Az első szerző munkáját az OTKA K108992 pályázat támogatta.

\section{Irodalom}

Allan H. H. (1936): Additions to the Alien Flora of New Zealand. - Transactions and Proceedings of the Royal Society of New Zealand 65: 1-9.

ANON. (2009): Trifolium L. - In: KIRÁLY G. (szerk.), Új magyar füvészkönyv. Magyarország hajtásos növényei. Határozókulcsok. [New Hungarian Herbal. The Vascular Plants of Hungary. Identification Key.] Aggteleki Nemzeti Park Igazgatóság, Jósvafö, pp. 255-259.

Bartha D., Király G., Schmidt D., Tiborcz V., BARina Z., CsiKy J., JAKAB G., LESku B., SChMotZer A., VidÉKi R., VojtKó A. \& Zólyomi Sz. (szerk.) (2015): Magyarország edényes növényfajainak elterjedési atlasza [Distribution atlas of vascular plants of Hungary.] Nyugat-magyarországi Egyetem Kiadó, Sopron, 329 pp.

BoRHIDI A. (1995): Social behaviour types, the naturalness and relative ecological indicator values of the higher plants in the Hungarian flora. - Acta Botanica Academiae Scientiarum Hungaricae 39: 97-181.

Coombe D. E. (1968): Trifolium L. - In: Tutin T. G., Heywood V. H., Burges N. A., Moore D. M., Valentine D. H., Walters S. M. \& WebB D. A. (eds), Flora Europaea. Volume 2., Cambridge University Press, Cambridge, pp.: 157-172.

Dihoru G. \& NEgReAn G. (2009): Cartea roşie a plantelor vasculare din România. [Red Book of Vascular Plants of Romania.] - Editura Academiei Române, Bucureşti, 630 pp.

HERRMANN N. \& LinKE C. (2006): Beiträge zur Biologie und Lebensgeschichte von Trifolium ornithopodioides L. (Fabaceae). - Drosera 1 (2): 1-26.

JАКАВ G. (2005): Adatok a Dél-Tiszántúl flórájának ismeretéhez II. - Flora Pannonica 3: 91-119.

JАKAB G. (szerk.) (2012): A Körös-Maros Nemzeti park növényvilága. - Körös-Maros Nemzeti Park Igazgatóság, Szarvas, $413 \mathrm{pp}$.

Jakab G., Tóth T., Kertész É., Virók V., Bátori Z., Molnár Z., MolnáR V. A. \& NótáRi K. (2015): Trifolium ornithopodioides (L.) Sm. - In: Bartha D., Király G., Schmidt D., Tiborcz V., Barina Z., Csiky J., JAKAB G., Lesku B., Schmotzer A., VidéKi R., Vojtкó A. \& Zólyomi Sz. (szerk.), Magyarország edényes növényfajainak elterjedési atlasza. [Distribution atlas of vascular plants of Hungary]. Nyugatmagyarországi Egyetem Kiadó, Sopron, p. 160.

KIRÁLY G. (szerk.) (2007): A magyarországi edényes flóra veszélyeztetett fajai. [Red list of the vascular flora of Hungary.] - Saját kiadás, Sopron, 73 pp.

KóRA J. (2011): Trifolium ornithopodioides (L.) SM. - In: KiRÁLY G., ViróK V. \& MolnÁR V. A. (szerk.), Új magyar füvészkönyv. Magyarország hajtásos növényei. Ábrák. [New Hungarian Herbal. The Vascular Plants of Hungary. Illustrations.] Aggteleki Nemzeti Park Igazgatóság, Jósvafő, 676 pp.

LESKu B. \& MolNÁR A. (2007): A Hortobágy növényritkaságai. - Hortobágyi Nemzeti Park Igazgatóság, Debrecen, $120 \mathrm{pp}$.

Simon T. (1997): A magyarországi edényes flóra határozója. - Nemzeti Tankönyvkiadó, Budapest, 892 pp.

SzujKó-Lacza J., Fekete G., Kováts D., Szabó L. \& Siroki Z. (1982): The vascular plants of the Hortobágy National Park. - In: SzUjKó-LACZA J. (szerk.), The Flora of the Hortobagy National Park. Akadémiai Kiadó, Budapest, pp.: 105-169.

SzujKó-LaCZA J. \& KovÁts D. (szerk.) (1993): The Flora of the Kiskunság National Park in the Danube-Tisza mid-region of Hungary. Vol. 1.: The flowering plants. - Magyar Természettudományi Múzeum, Budapest, $469 \mathrm{pp}$.

Török P., Miglécz T., Valkó O., Tóth K., Kelemen A., Albert Á., Matus G., Molnár V. A., Ruprecht E., Papp L., DEÁK B., HoRVÁTH O., TAKÁCS A., HüSE B. \& TóTHMÉRÉSz B. (2013): New thousand-seed weight records of the Pannonian flora and their application in analysing social behaviour types. - Acta Botanica Hungarica 55 (3-4): 429-472.

Webb C. J., Sykes W. R. \& Garnock-Jones P. J. (eds) (1988): Flora of New Zealand. Volume IV. Naturalised Pteridophytes, Gymnosperms, Dicotyledons. - Christchurch, New Zealand. 1365 pp. 


\section{Hivatkozott világháló oldalak}

Brouillet L., Coursol F., Favreau M. \& Anions M. (eds) (é.n.): 2010+ VASCAN, the Database of Vascular Plants of Canada. http://data.canadensys.net/vascan/taxon/5927 (Hozzáférés: 2016.09.21.)

Coombe D. E. (é.n.): Trifolium ornithopodioides. - In: Online Atlas of the British and Irish Flora. http://www.brc.ac.uk/plantatlas/index.php?q=node/1942 (Hozzáférés: 2016.09.21.)

13/2001. (V.9.) KöM rendelet a védett és a fokozottan védett növény- és állatfajokról, a fokozottan védett barlangok köréröl, valamint az Európai Közösségben természetvédelmi szempontból jelentős növényés állatfajok közzétételéről. http://njt.hu/cgi_bin/njt_doc.cgi?docid=56000.313262 (Hozzáférés: 2016.09.21.)

Beérkezett / received: 2016. 09. 04. • Elfogadva / accepted: 2016. 10. 05. 